\title{
A ação do Espírito Santo em Jesus Cristo: um aprofundamento da relação entre cristologia e pneumatologia na cristologia pós-conciliar
}

\author{
Orientador: Paulo Cezar Costa \\ Doutoranda: Angela Cristina Germine P. Caldeira \\ Área de Concentração: Teologia Sistemático-Pastoral \\ Linha de Pesquisa: Fé e Cultura
}

Na vida de Jesus de Nazaré se destaca a presença e ação do Espírito Santo ao longo do seu ministério messiânico para afirmar a centralidade da relação entre cristologia e pneumatologia. Jesus Cristo é o mistério mais importante de toda a realidade, revelado de modo único, original, irrepetível e insuperável no Espírito. O caminho do Espírito no evento de Cristo é o argumento principal desta tese. O horizonte teológico, assim com a realidade humana são desafios a enfrentar na atualidade. Para tal, primeiramente foi colocado em destaque a relação entre Cristo e o Espírito no NT, nos momentos principais, onde acontece a manifestação do Espírito na vida de Cristo: na encarnação, no batismo e no mistério pascal. Nestes três eventos a presença operante do Espírito revela a constituição divina e humana de Cristo e a universalidade de sua salvação. Após o testemunho bíblico e pós-bíblico destacou-se a presença do Espírito Santo na renovada atenção do Concílio Vaticano II em seus aspectos cristológicos, pneumatológicos e eclesiológicos. O concílio representou uma renovação da Igreja, entretanto com limitações e dificuldades para articular seu conteúdo. Os textos conciliares impulsionaram a produção teológica pós-conciliar valorizando a cristologia pneumatológica, destacando-se as obras de Yves Congar, Walter Kasper e Marcello Bordoni. A reflexão pós-conciliar afetou particularmente a posição teológica na América Latina, por isso foi relevante analisar a presença do Espírito na cristologia latino-americana. Por último, alguns pontos emergem na contemporaneidade, que indicam a necessidade da reflexão teológica de aprofundar a dimensão pneumática do mistério de Cristo.

Palavras-chave: Cristologia. Pneumatologia. Vaticano II. 